\title{
JOB CHANGES AT OLDER AGES: \\ EFFECTS ON WAGES, BENEFITS, AND OTHER JOB ATTRIBUTES
}

\author{
Richard W. Johnson and Janette Kawachi*
}

CRR WP 2007-4

Released: February 2007

Draft Submitted: January 2007
Center for Retirement Research at Boston College Hovey House 140 Commonwealth Avenue
Chestnut Hill, MA 02467
Tel: 617-552-1762 Fax: 617-552-0191
http://www.bc.edu/crr

* Richard W. Johnson is a senior research associate at the Urban Institute. Janette Kawachi is a research associate at the Urban Institute. The research reported herein was performed pursuant to a grant from the U.S. Social Security Administration (SSA) funded as part of the Retirement Research Consortium. The findings and conclusions are solely those of the authors and do not represent the views of SSA, any agency of the Federal Government, the Urban Institute, or Boston College. The authors are grateful to Desmond Toohey for excellent research assistance.

(c) 2007, by Richard W. Johnson and Janette Kawachi. All rights reserved. Short sections of text, not to exceed two paragraphs, may be quoted without explicit permission provided that full credit, including (C) notice, is given to the source. 


\title{
About the Center for Retirement Research
}

The Center for Retirement Research at Boston College, part of a consortium that includes parallel centers at the University of Michigan and the National Bureau of Economic Research, was established in 1998 through a grant from the Social Security Administration. The Center's mission is to produce first-class research and forge a strong link between the academic community and decision makers in the public and private sectors around an issue of critical importance to the nation's future. To achieve this mission, the Center sponsors a wide variety of research projects, transmits new findings to a broad audience, trains new scholars, and broadens access to valuable data sources.

\author{
Center for Retirement Research at Boston College \\ Hovey House \\ 140 Commonwealth Avenue \\ Chestnut Hill, MA 02467 \\ phone: 617-552-1762 fax: 617-552-0191 \\ e-mail: crr@bc.edu \\ www.bc.edu/crr
}

\author{
Affiliated Institutions: \\ American Enterprise Institute \\ The Brookings Institution \\ Center for Strategic and International Studies \\ Massachusetts Institute of Technology \\ Syracuse University \\ Urban Institute
}




\begin{abstract}
One potential way to manage the rapidly growing costs of supporting older Americans is to increase labor supply at older ages. However, questions persist about the quality of available jobs. This study examines older Americans' employment opportunities by studying job changes at older ages. Using data from the Health and Retirement Study, it compares wages, benefits, and other job attributes on new and former jobs for adults ages 45 to 75 who changed employers between 1986 and 2004. Because older people who choose to work after retiring voluntarily from long-term jobs may face different employment prospects than displaced older workers, the analysis considers how employment changes vary by the reasons workers give for job separations. Most people who switched employers at older ages moved to jobs that differed substantially from their previous jobs. The vast majority of older job changers moved into different occupations and industries. They were more likely to be self-employed, work part-time, and keep flexible hours at their new jobs than their old jobs. The new jobs generally involved less stress, less physical effort, and fewer managerial responsibilities. More older job changers enjoyed their new jobs than their old jobs. However, most older workers experienced sharp hourly wage reductions when they switched employers. They were also less likely to receive pension coverage or health benefits after they moved to new jobs. Although the findings do not raise concerns about the quality of post-retirement jobs, they suggest that older displaced workers face special challenges in the labor market.
\end{abstract}




\section{Introduction}

Population aging is focusing attention on the costs of supporting older Americans. As life expectancy increases, fertility rates decline, and the unusually large baby boom cohorts born after 1945 approach old age, the share of the population ages 65 and older will soon begin to soar. At the same time, older men are retiring earlier and working less than they did 30 years ago. As a result, people are spending more time in retirement than ever before. If current employment patterns continue, population aging will reduce the number of workers in the economy for every retiree, reducing economic growth, straining Social Security and Medicare finances, and limiting tax revenue available to fund other government functions.

One potential solution is to increase older adults' labor supply, but questions persist about the quality of available jobs. By delaying retirement and remaining at work, older Americans could produce more goods and services, promoting economic growth and contributing to income and payroll taxes that finance all public services. Many older Americans say they want to keep working and labor force participation rates at older ages have been rising recently, after falling for decades. However, older workers often prefer to reduce their hours and responsibilities, rather than continue working full-time at demanding jobs. Older workers’ preferences for fewer hours and responsibilities force many to move to new jobs and forego the specific human capital they accumulated with their long-term career employers. Workers also lose specific human capital when they move to new employers after layoffs, and those who lose their jobs at older ages do not have time to accumulate much experience with their new employers. As a result, older job changers often earn less on their new jobs than on their long-term career jobs, limiting the attractiveness of work at older ages. 
This paper examines older Americans' employment opportunities by studying job changes at older ages. It compares wages, benefits, and other job attributes on new and former jobs for a large sample of older Americans who changed employers between 1986 and 2004. Because older people who choose to work after retiring voluntarily from long-term jobs may face different employment prospects than displaced older workers, the analysis considers how employment changes vary by the reasons workers give for job separations and their tenure on previous jobs. The results show that about 85 percent of older people who worked after retirement changed occupations, and about 80 percent changed industries. The median hourly wage in post-retirement jobs was less than half the median wage in pre-retirement long-term career jobs, but post-retirement work was less stressful.

\section{Background}

With lifespan increasing and average retirement ages failing to keep pace, people are spending more time in retirement than ever before. Women who reached age 65 in 2000 could expect to live another 20 years, up from 16 years for women who turned 65 in 1950 (Social Security Trustees 2006). Between 1950 and 2000, male life expectancy at age 65 increased by nearly three years. Median retirement ages, by contrast, declined steadily for men over the period, falling from 67 to 62 (Gendell 2001). In 2005, only 69 percent of men ages 55 to 64 participated in the labor force, down from 90 percent in 1948 (Bureau of Labor Statistics 2006). Participation rates fell even more rapidly for men ages 65 and older, plunging from 47 percent to 20 percent between 1948 and 2005. ${ }^{1}$

\footnotetext{
${ }^{1}$ Labor force participation rates for older women have increased over the past 50 years, however, as married women of all ages moved into the labor force. Between 1948 and 2005, the share of women participating in the labor force increased from 24 percent to 57 percent (Bureau of Labor Statistics 2006).
} 
The trend toward longer retirements, combined with the aging of the population, is straining the economy's capacity to support its oldest members. The U.S. Census Bureau (2004) projects that the share of the adult U.S. population ages 65 and older will reach 27 percent by 2050, up from 17 percent in 2000 and 12 percent in 1950. Based on current employment patterns, the Social Security trustees project that between 2000 and 2030 the number of workers paying into the system per beneficiary will decline from 3.4 to 2.2 (Social Security Trustees 2006). The reduction in the number of workers available to support each retiree will force cutbacks in retirement benefits or other government services, tax hikes, or increased government borrowing. Current projections indicate that Social Security will begin paying out more funds than it collects in taxes in 2017, and that the Social Security trust fund will be exhausted by 2040 (Social Security Trustees 2006).

\section{Benefits of Working Longer}

The economic pressures created by an aging population could be mitigated if people delayed retirement. If men and women continue to work at the age-specific rates that prevailed in 2000, the number of workers per nonworking adult ages 65 and older will fall from 4.5 in 2000 to 3.3 in 2020. However, if men ages 55 and older instead worked at the rate that prevailed in 1950 (when jobs were less physically demanding and health problems were more prevalent) and everyone else worked at the 2000 rates, then the ratio of workers to nonworking older adult would fall to only 4.1 by 2020 (Johnson and Steuerle 2004). Additional work at older ages would increase the production of goods and services, spurring economic growth and raising tax revenue. If every worker delayed retirement by five years, relative to retirement plans based on current work patterns, the additional revenue generated by income and payroll taxes would more 
than cover the Social Security trust fund deficit for the foreseeable future (Butrica, Smith, and Steuerle 2006).

There are already encouraging signs of increased labor supply at older ages. As jobs become less physically demanding (Johnson 2004; Steuerle, Spiro, and Johnson 1999) and health status at older ages improves (National Center for Health Statistics 2006), more older people are now physically able to remain at work than in the past. About two-thirds of working adults ages 50 to 70 who did not consider themselves to have retired from a previous job reported in 2003 that they planned to work in retirement or never retire (AARP 2003). Nearly one-third of workers ages 51 to 55 reported in 2004 that they planned to work full-time past age 65, up from 27 percent in 1992 (Mermin, Johnson, and Murphy 2006). Declines in traditional defined benefit pension plans and retiree health plans and increases in educational attainment accounted for nearly all of the change in work plans. Employment rates are already rising slowly among older men. Between 1993 and 2005, the share of men ages 65 and older that were working increased from 16 to 20 percent (Bureau of Labor Statistics 2006).

\section{Challenges Faced by Older Workers}

Although many older people say they want to remain at work, questions persist about employers' demand for older workers and their suitability for available jobs. Older workers are not perfect substitutes for younger workers. Because most older people attended school many years ago, their education may be less relevant to today’s workplace than the more recent schooling of younger workers, especially in fields undergoing rapid technological change (Bartel and Sicherman 1993). Physical abilities and some cognitive skills tend to decline with age, potentially reducing older adults’ productivity. For example, finger dexterity diminishes rapidly as people grow older, and numerical ability, the capacity to master new material, and general 
intelligence all peak by age 35 and then erode over time (Avolio and Waldman 1994; Verhaegen and Salthouse 1997). However, cognitive skills that rely on accumulated knowledge, including verbal ability, do not appear to decline with age (Horn and Cattell 1966). Acquired knowledge, enhanced communication skills, and sharper decision-making abilities can often offset agerelated declines in mental efficiency. For example, one study found that older hotel reservation clerks were more productive than their younger colleagues, even though they handled fewer calls, because their superior communications skills generated more bookings per call (McNaught, Barth, and Henderson 1989). Overall, many studies have found no significant relationship between productivity and age, as measured by work output and supervisory ratings (McEvoy and Cascio 1989).

Many employers say they value older workers' abilities and contributions. In a recent survey 56 percent of private-sector employers reported that older white-collar workers were more productive than their younger counterparts, while only 6 percent said that older workers were less productive (Munnell, Sass, and Soto 2006). Employers particularly valued older workers' knowledge of workplace procedures and their ability to interact with customers. However, they were not as favorably disposed toward older workers in nonmanagerial positions. Nearly one in five private-sector employers reported that older rank and file workers were less productive than their younger counterparts. And about two in five employers said that older workers were more expensive than younger workers.

Despite these generally favorable reports from employers, some older people may also face discrimination in the workplace. Although age discrimination is difficult to measure, a recent experimental study found that older job applicants in Florida were about 18 percent less likely to receive call backs and about 46 percent less likely to obtain interviews than younger job 
applicants with identical qualifications (Lahey 2005). Additionally, about two-thirds of workers ages 45 to 74 reported in a 2002 survey that they believed age discrimination persists in the workplace (AARP 2002).

Older people’s preferences for reduced workloads may also create employment barriers. Although most workers ages 50 to 70 who do not consider themselves to be retired say they plan to work in retirement, about two-thirds of those planning to work say they want part-time employment (AARP 2003). Older workers almost always switch employers when they transition from full-time work to part-time work (Ruhm 1990). Few employers have formal phased retirement programs that allow older employees to reduce their work hours while remaining on the payroll. Although many employers without formal programs say they would allow older workers to reduce their hours before they officially retire, only 40 percent of these firms would allow informal phased retirees to begin drawing their pension benefits (Hutchens 2003). Most older workers cannot afford to cutback their work effort unless they have access to retirement benefits. About one-third of workers ages 61 to 71 who had left full-time career employment defined as a job held for 10 or more years — between 1992 and 2002 moved to part-time employment on another job (Cahill, Giandrea, and Quinn 2006.)

Because job separations involve the loss of firm-specific human capital — skills unique to a particular employer-employee relationship — productivity and hence wages often fall when older workers move to new jobs, whether or not they choose to separate so they can reduce their workloads. ${ }^{2}$ Post-retirement jobs generally pay much lower hourly wages than pre-retirement

\footnotetext{
${ }^{2}$ Job separations by older workers will also reduce compensation for those whose earnings from their former employers exceeded the value of their marginal productivity. Some evidence suggests that workers enter into implicit long-term contracts with their employers that pay them less than the value of their marginal productivity early in their careers and more later in their careers (Lazear 1979; Lazear and Moore 1984). These arrangements provide workers with incentives to work hard, because shirkers they run the risk of being fired and losing substantial payouts near the end of the career.
} 
jobs (Maestas 2005). Employers have little incentive to invest in training for older workers because they will retire fairly soon, although older workers are less likely to switch jobs than younger workers (Farber 1999).

Job prospects may be especially bleak for older people laid off from their previous jobs, who did not voluntarily leave their former employers to take advantage of better jobs. About 19 percent of people ages 51 to 61 in 1992 experienced job layoffs between 1992 and 2002 (Johnson, Mermin and Uccello 2005). Older people are less likely to lose their jobs than younger people, but their many years of service — not their age — appear to protect them from displacement (Munnell, Sass, Soto, and Zhivan 2006). Job displacements often lead to substantial earnings losses (Jacobson, LaLonde, and Sullivan 1993), and many older people laid off from their jobs never return to work (Chan and Stevens 2001).

\section{Methods}

Our study of job changes at older ages was based on data from the Health and Retirement Study (HRS), a nationally representative longitudinal survey of older Americans. Conducted by the University of Michigan with primary funding from the National Institute on Aging, the survey began in 1992 with interviews of 9,814 adults born between 1931 and 1941, when they were ages 51 to 61. In 1998 the HRS also began interviewing 3,849 adults born between 1924 and 1930, who were ages 68 to 74, and another 3,107 adults born between 1942 and 1947, who were ages 51 to 56. Additionally, 3,373 respondents born between 1948 and 1953 were added to the survey in 2004, when they were ages 51 to $56 .{ }^{3}$ Respondents were reinterviewed every other

\footnotetext{
${ }^{3}$ In 1993 the HRS also began collecting data from a sample of adults born before 1924, who were ages 70 and older at baseline. We did not include these cohorts in our study because the HRS did not collect detailed employment information from them in the early years of the survey. Additionally, the HRS interviewed the spouses of respondents even if they were born before or after the specified years.
} 
year. The HRS collects information on a wide range of topics, including work status, employment histories, earnings, health status, and demographics. The most recent data available when our study began were collected in 2004 .

At each interview the survey asked respondents about their work status and asked workers about the attributes of their current jobs. Available job information included earnings (reported on an hourly, weekly, biweekly, monthly, or annual basis), occupation, industry, number of years on the job, employer pension and health insurance coverage, coverage by a union contract, usual weekly work hours, weeks worked per year, and self employment. The survey also asked respondents about job requirements and responsibilities, how much they enjoyed their jobs, and how flexible their jobs were. Additionally, respondents indicated whether they continued to work at the same job they held at the previous interview. Those who left their old jobs were asked why they separated.

The survey also collected job histories at each baseline interview. For the most recent previous job that lasted for at least five years, respondents reported their occupation and industry, the year they began working at the job and the year they left, earnings in the year they left, pension coverage, and the reason for leaving.

\section{Sample and Measures}

We used the longitudinal data to compare job characteristics on new and former jobs for older job changers. Using the retrospective information on previous jobs going back six years, we restricted the sample to job changes (a separation and subsequent reemployment) between 1986 and 2004 by adults ages 45 to $75 .{ }^{4}$ Our sample consisted of 8,362 job changes by 5,541

\footnotetext{
${ }^{4}$ The youngest respondents were age 51 when first interviewed, and the analysis included jobs that were left up to six years prior to the baseline survey. For respondents who entered the survey in 1992, jobs that ended in 1986 or later in the job history sections were included; for those who entered in 1998, jobs ending in 1992 or later were included; and for those who entered in 2004, jobs ending in 1998 or later were included.
} 
different respondents. ${ }^{5}$ Because the impact of job changes likely depends on whether workers voluntarily left their jobs, we compared pre- and post-change job attributes for four types of job separations: retirements (followed by post-retirement work), job layoffs (including business closures and workers who reported being "let go"), quits (including workers who left their employers for "better jobs"), and separations for other reasons (including relocation, poor health and disability, family or child care responsibilities, marriage, spouse's preferences, personal problems, and dissatisfaction with work hours or length of commute). The analysis also differentiated between workers who spent more than 10 years on the previous job and those with less tenure, because the consequences of leaving long-term jobs are likely to be especially pronounced.

The analysis examined how wages, industry, and occupation changed when older people switched jobs. We compared mean and median hourly wages on new and old jobs, and computed the share of job changers whose hourly wages increased by 10 percent after they changed jobs, the share whose wages fell between 10 and 25 percent, between 25 and 50 percent, and more than 50 percent, and the share whose wages changed less than 10 percent. For respondents who reported their earnings on a weekly or less frequent basis, we computed the hourly wage by dividing reported earnings by usual hours worked. We also compared occupation and industry distributions on new and old jobs and computed the share of job changers who switched occupations and industries. Restricted-release versions of the HRS, which we obtained from the University of Michigan, include information on detailed occupations and industries, defined by three-digit Census codes.

\footnotetext{
${ }^{5}$ Our sample excluded exits from some short-term jobs. The retrospective data collected at the baseline interviews referred only to jobs held for at least five years. Additionally, the analysis excluded jobs that began and ended
} 
The analysis also compared other attributes of old and new jobs held by older workers. These attributes included pension and health insurance coverage, coverage by a union contract, part-time status, self-employment, stress, physical demands, hours flexibility, responsibility for pay and promotion decisions about other workers, and whether workers enjoyed their jobs. For each characteristic, we computed the share of workers with the characteristic on the old job, the new job, the old job but not the new job, and the new job but not the old job. We defined work as part-time if it involved fewer than 35 hours in a usual week. We classified a job as stressful if respondents agreed or strongly agreed with the statement that their job “involves a lot of stress,” and as having flexible work hours if respondents said they could reduce the number of hours in their regular work schedule. Workers who reported that their jobs required physical effort all or almost all of the time or most of the time were considered to have physically demanding jobs. The analysis classified respondents as enjoying work if they agreed or strongly agreed with the statement, "I really enjoy going to work."

\section{Results}

Overall, only about 18 percent of job changes at older ages followed retirement (table 1). About 33 percent followed layoffs, 30 percent followed quits, and 20 percent followed separations for other reasons, such as family relocations, health problems, or family responsibilities. Only about 4 in 10 job changes at older ages involved separations from longterm jobs, lasting more than 10 years. Job changers who left long-term jobs were more likely to have retired from their previous jobs than those who left shorter-term jobs. Retirees accounted for about 35 percent of job changers who spent more than 10 years with their previous employers, compared with only 7 percent of job changers with 10 or fewer years of service with

during the two-year periods between the HRS interviews, because respondents provided less information about these jobs than jobs held at the time of the interviews. 
their previous employers. Job changers who spent 10 or fewer years on the previous job were nearly twice as likely to quit the previous job as those with more than 10 years of service.

Older workers retiring from long-term jobs were generally older and better educated than those who left for other reasons (table 2). For example, only about 36 percent of retirees were ages 55 and younger, compared with about 61 percent of those who were laid off and 64 percent of those who quit. About one quarter of retirees, but only 6 percent of those who quit their former jobs, were older than 60. College graduates accounted for more than one-third of retirees, but only about one-fifth of workers who were laid off. Additionally, retirees were disproportionately male, with men accounting for about 67 percent of retirees but only 56 percent of those who quit their previous jobs.

The gender and educational composition of job changers did not vary as much across different types of job separations among those who spent less time on their previous jobs. For example, college graduates accounted for about 29 percent of retirees with no more than 10 years of service on the previous job, 29 percent of workers who quit their previous jobs, and 19 percent of laid-off workers. However, workers who retired from short-term jobs were relatively old; 51 percent were more than 60 years old.

\section{Wage Differences}

Overall hourly wages fell by a few dollars when older workers changed jobs. Mean wages fell by about 13 percent for all job changers, from $\$ 18.57$ to $\$ 16.23$ (table 3). The decline was a bit steeper for men than women. Nonetheless, male job changers earned about 50 percent more on new jobs than female job changers. Wages fell much more sharply for workers who left long-term jobs lasting more than 10 years than for those who left shorter-term jobs, because older workers with many years of service earned more on their former jobs than those with less 
tenure. Average wages declined by 24 percent when older workers left long-term jobs, and median wages fell by 38 percent. For workers who left short-term jobs, by contrast, differences in the average wage were insignificant. As a result, older workers who left long-term employers earned on average only $\$ 1.22$ more on their new jobs than those who left shorter-term employers.

Hourly wages fell more sharply for older workers who retired from their previous jobs than those who separated for other reasons. Average wages for retirees who continued to work declined by 36 percent, and median wages plunged by 50 percent. Displaced older workers who found other employment also experienced wage losses, averaging about 12 percent. Wages among retirees and displaced workers generally fell more steeply for men than women and for those leaving long-term jobs than those leaving shorter-term jobs. For example, median wages for men laid-off from long-term jobs who found other employment fell by about 25 percent. However, job changers who quit their jobs or left for other reasons did not experience substantial wage losses. Average hourly wages fell by less than $\$ 2$ for those who quit long-term jobs, and increased by more than $\$ 1$ for those who quit short-term jobs.

About one-half of men and 40 percent of women who retired from long-term jobs and were reemployed elsewhere experienced hourly wage losses of at least 50 percent (table 4). By comparison, only about 25 percent of men laid-off from long-term jobs, 16 percent of men who quit long-term jobs, and 24 percent of men who left long-term jobs for other reasons experienced such large relative wage declines. Substantial wage losses were much less prevalent among workers who left short-term jobs. Overall, only 9 percent of all job changers who left short-term jobs experienced hourly wage losses of at least 50 percent, including 16 percent of retirees. Nearly 4 in 10 job changers who left short-term jobs — and nearly one-half of job quitters — 
experienced hourly wage gains of at least 10 percent. Among older workers separating from long-term jobs, about one-quarter received a raise in hourly wages of 10 percent of more, including about 39 percent of those who quit their long-term jobs.

Wages dropped more dramatically for job changers retiring from long-term jobs than for other jobs changers because they earned more on their previous jobs. Retirees from long-term jobs earned about 32 percent more on their previous jobs than those who quit long-term jobs, and about 40 percent more than those who left long-term jobs because of layoffs or other reasons. Among job changers who left long-term jobs, retirees earned about $\$ 1$ more on their new jobs than displaced workers, but about $\$ 2$ less than those who quit their previous jobs.

\section{Occupational and Industry Changes}

Older job changers leaving long-term employment tended to move out of managerial occupations and into sales and service occupations (table 5). For example, among those who left jobs held for more than 10 years, 13 percent were employed in managerial positions in their new jobs, compared with 21 percent in managerial positions in their former long-term jobs. The movement into sales positions was especially dramatic for those who retired from long-term jobs. About 12 percent worked in sales on their new jobs, up from 5 percent on former jobs. Laid-off workers were also significantly less likely to be employed in managerial positions on their new jobs than their old jobs, and were significantly more likely to be employed in sales and services positions with their new employers.

Only about 23 percent of older job changers who left long-term employers remained in the same detailed occupation category on their new jobs, defined by three-digit Census codes. More than half (about 57 percent) moved into different broadly defined occupations. ${ }^{6}$ Retirees

\footnotetext{
${ }^{6}$ The broad occupational groups consisted of 17 different categories: managers; professionals and technical support; sales; clerical; private household services; protection services; food preparation services; health services; personal
} 
were significantly more likely to change occupations than those who switched employers for other reasons. Only about 15 percent of retirees who left long-term employers remained in the same detailed occupation category, and 64 percent moved into different broadly defined occupational categories.

Job separations did not alter the occupational distribution much for older workers who left short-term jobs, except that fewer workers were employed in managerial positions on new jobs than old jobs. Nonetheless, most older job changers who left short-term jobs also changed occupations. For example, 59 percent of all job changers who left short-term jobs and 65 percent of retirees moved into different broadly defined occupations with their new employers.

Many older job changers separating from long-term employers exited the manufacturing and public administration industries and moved into the trade and service industries (table 6). About 21 percent of former jobs were in manufacturing, compared with just 11 percent of new jobs. The industry mix for old and new jobs differed sharply for retirees who left long-term jobs. For example, just about 2 percent worked in business and repair services before retirement, compared with 12 percent after retirement. Retirement increased the share in trade from about 5 percent to 14 percent and the share in entertainment and recreation services from 1 percent to 8 percent. However, the share in manufacturing fell from about 22 percent to 7 percent upon retirement, and the share in public administration fell from 17 percent to 4 percent.

Long-term employees in manufacturing were particularly vulnerable to layoffs between 1986 and 2004. The manufacturing sector accounted for about 30 percent of jobs lost to displacement but only about 21 percent of all job changes. By contrast, only 10 percent of layoffs among older workers occurred in the professional services industries, compared with about 22 operators; transport operators; handling operators; and members of the Armed Forces. 
percent of all job separations. Many older displaced workers who found new jobs left the manufacturing industry.

Only about one in five job changers who retired from long-term jobs continued to work in the same narrowly defined industry as before they retired. By contrast, about one-third of older job changers who quit their previous jobs continued to work in the same narrow industry. About 65 percent of employed retirees and 60 percent of displaced workers moved into different broadly defined industry groups. ${ }^{7}$

As with occupational changes, older workers who left short-term jobs were less likely to change industries than those who left long-term jobs. Nonetheless, movement across industries was widespread among those who left short-term jobs. Overall, fewer than one-third of older job changers who left jobs that lasted no more than 10 years remained in the same narrowly defined industries that employed them before the separation, and more than one-half moved into different broadly defined industry groups.

\section{Fringe Benefits Among Job Changers}

About 7 in 10 older workers who left long-term jobs had pension coverage on their old jobs, but only about one in four had coverage on their new jobs (table 7). Employed retirees were most likely to lose pension coverage when they changed employers. About 91 percent of retirees leaving long-term employers had pension coverage before they retired, but only about 15 percent had coverage on post-retirement jobs. For older displaced workers who found other employment, pension coverage rates fell from 64 percent on their old jobs to 30 percent on their new jobs.

More than 6 in 10 reemployed displaced workers with pension coverage on their old jobs lacked

\footnotetext{
${ }^{7}$ The broad industry groups consisted of 13 different categories: agriculture, forestry, and fishing; mining and construction; nondurable manufacturing; durable manufacturing; transportation; wholesale trade; retail trade; finance, insurance, and real estate; business and repair services; personal services; entertainment and recreation; professional and related services; and public administration.
} 
coverage on their new jobs (40.3/64, or 63 percent). Only about 6 percent had coverage on the new job but not the old one. Older workers who quit long-term jobs were less likely to have pension coverage on their previous jobs and more likely to have coverage on their new jobs. In fact, about 12 percent of job quitters moved from jobs with no pension coverage to covered jobs. Nonetheless, slightly more than half of older workers who voluntarily left jobs with pension coverage (but did not describe themselves as retired) moved to jobs without pension coverage (30.8/58.2, or 53 percent).

Fewer older workers lost health insurance coverage than pension coverage when they separated from their employers. Overall, about 71 percent of older workers who left long-term jobs received health benefits on their old jobs, and 55 percent received benefits on their new jobs. Retirees were more likely than older job changers who separated for any other reason to have health insurance coverage on both pre- and post-separation jobs.

Older job changers who left short-term jobs were less likely that those who left long-term jobs to receive pension or health insurance coverage from their former employers. They were also somewhat less likely than those who left long-term jobs to receive health benefits on their new jobs, but about as likely to receive pension coverage on the new jobs.

\section{Other Job Attributes}

Many older workers who changed jobs moved to part-time work, self-employment, and jobs offering flexible work arrangements (table 8). Forty-three percent of older workers who left long-term jobs worked part-time on their new jobs, 25 percent were self-employed, and 50 percent worked in flexible jobs. By comparison, only 15 percent worked part-time and 28 percent had flexible work arrangements on their pre-separation jobs. Part-time work, selfemployment, and flexible work arrangements were especially common on post-retirement jobs. 
About 56 percent of employed retirees who left long-term jobs moved from full-time work to part-time work, 28 percent moved from wage and salary employment to self-employment, and 45 percent moved from less flexible jobs to more flexible jobs.

Few older job changers moved to jobs covered by labor union contracts. About 33 percent of older workers who left long-term employers were covered by union contracts on their previous jobs, but only 11 percent were covered on their new jobs. About 36 percent of employed retirees who left long-term employers moved from union jobs to nonunion jobs.

Older job changers — especially retirees — who left long-term employers generally preferred their new jobs to their old jobs (table 9). About 93 percent of employed retirees who left long-term employers said they enjoyed their new jobs, whereas only 77 percent said they enjoyed their old jobs. About one in five reported enjoying their new jobs but not their old jobs. Even reemployed displaced workers were more likely to enjoy their new jobs than their former jobs.

Smaller shares of new jobs held by older job changers than old jobs involved stress, much physical effort, or managerial responsibilities. For example, about 43 percent of employed retirees who left long-term jobs and 29 percent of workers who had been laid-off from long-term jobs said their old jobs were stressful but their new jobs were not. About 14 percent of older job changers who left long-term jobs made pay and promotion decisions on their new jobs, compared with 25 percent making such decisions on their old jobs. Although physical job demands were less prevalent on new jobs than former jobs, the differences were relatively modest. 


\section{Conclusions}

Workers ages 45 to 75 who switched employers between 1986 and 2004 tended to move to jobs that differed substantially from their previous jobs. The vast majority of older job changers moved into different occupations and industries. They were more likely to be selfemployed, work part-time, and keep flexible hours at their new jobs than their old jobs. The new jobs generally involved less stress, less physical effort, and fewer managerial responsibilities. More older job changers enjoyed their new jobs than their old jobs. However, most older workers experienced sharp reductions in hourly wages when they switched employers. They were also less likely to receive pension coverage or health benefits after they moved to new jobs.

The consequences of job changes at older ages depended crucially on why workers changed jobs and how long they held their former jobs. Differences between old and new jobs were starkest among workers who said they retired from their previous long-term jobs, and often insignificant among workers who said they quit their previous jobs. For example, about one-half of men and 40 percent of women who worked after retiring from jobs that they held for more than 10 years experienced hourly wage declines of at least 50 percent. However, only about one in six older men and one in eight older women who quit long-term jobs experienced such steep wage declines on their new jobs.

Our findings should not raise concerns about the quality of post-retirement jobs.

Although these jobs did not pay very much on average, they were less stressful and more flexible than career jobs, and more than 9 in 10 people working in retirement said they enjoyed their jobs. Our comparisons of pre- and post-retirement jobs are consistent with the notion that older adults tend to use post-retirement jobs as bridges to complete withdrawal from the labor market, working at less demanding jobs that they enjoy and that supplement their retirement benefits. 
However, our results also suggest that people who lose their jobs at older ages often face special challenges in the labor market. Those able to find other employment generally ended up in different industries and occupations, earning much lower wages than on their former jobs. For example, about one-quarter of older men laid-off from long-term jobs earned hourly wages that were less than half as high as on their previous jobs. About 40 percent lost pension coverage and 25 percent lost health benefits. These findings suggest that as policymakers consider ways of encouraging work at older ages, they should pay special attention to the struggles of older displaced workers. 


\section{References}

AARP. 2002. Staying Ahead of the Curve: The AARP Work and Career Study. Washington, DC: AARP.

. 2003. "Staying Ahead of the Curve 2003: The AARP Working in Retirement Study.” http://assets.aarp.org/rgcenter/econ/multiwork_2003.pdf.

Avolio, Bruce J. and David A. Waldman. 1994. "Variations in Cognitive, Perceptual, and Psychomotor Abilities Across the Working Life Span: Examining the Effects of Race, Sex, Experience, Education, and Occupational Type.” Psychology and Aging 9(3): 430442.

Bartel, Ann P. and Nachum Sicherman. 1993. "Technological Change and Retirement Decisions of Older Workers.” Journal of Labor Economics 11(1): 162-83.

Bureau of Labor Statistics. 2006. "Labor Force Statistics from the Current Population Survey." http://data.bls.gov/PDQ/outside.jsp?survey=ln.

Butrica, Barbara, Karen Smith, and Eugene Steuerle. 2006. "Working for a Good Retirement.” CRR Working Paper No. 2006-8. Chestnut Hill, MA: Center for Retirement Research at Boston College.

Cahill, Kevin E., Michael D. Giandrea, and Joseph F. Quinn. 2006. "Retirement Patterns from Career Employment.” The Gerontologist 46(4): 514-523.

Chan, Sewin, and Ann Huff Stevens. 2001. "Job Loss and Employment Patterns of Older Workers.” Journal of Labor Economics 19(2): 484-521.

Farber, Henry S. 1999. "Mobility and Stability: The Dynamics of Job Change in Labor Markets.” In Handbook of Labor Economics, Vol. 3B, edited by Orley Ashenfelter and David Card (2439-83). Amsterdam: Elsevier Science B.V.

Gendell, Murray. 2001. "Retirement Age Declines Again in 1990s.” Monthly Labor Review 124(10): 12-21.

Horn, John L. and Raymond B. Cattell. 1966. "Refinement and Test of the Theory of Fluid and Crystallized General Intelligences.” Journal of Educational Psychology 57(5): 253-270.

Hutchens, Robert M. 2003. “The Cornell Study of Employer Phased Retirement Policies: A Report on Key Findings.” Ithaca, NY: School of Industrial and Labor Relations, Cornell University.

Jacobson, Louis S., Robert J. LaLonde, and Daniel G. Sullivan. 1993. "Earnings Losses of Displaced Workers. ” American Economic Review 83(4): 685-709. 
Johnson, Richard W. 2004. “Trends in Job Demands Among Older Workers, 1992-2002.” Monthly Labor Review 127(7): 48-56.

Johnson, Richard W., and Eugene Steuerle. 2004. "Promoting Work at Older Ages: The Role of Hybrid Pension Plans in an Aging Population.” Journal of Pension Economics and Finance 3(3): 315-37.

Johnson, Richard W., Gordon B. T. Mermin, and Cori E. Uccello. 2005. "When the Nest Egg Cracks: Financial Consequences of Health Problems, Marital Status Changes, and Job Layoffs at Older Ages.” CRR Working Paper No. 2005-18. Chestnut Hill, MA: Center for Retirement Research at Boston College.

Lahey, Joanna. 2005. “Age, Women, and Hiring: An Experimental Study.” NBER Working Paper 11435. Cambridge, MA: National Bureau of Economic Research.

Lazear, Edward P. 1979. “Why Is There Mandatory Retirement?” Journal of Political Economy 87(6): 1261-84.

Lazear, Edward P. and Robert L. Moore. 1984. “Incentives, Productivity, and Labor Contracts.” Quarterly Journal of Economics 99(2): 275-95.

Maestas, Nicole. 2005. "Back to Work: Expectations and Realizations of Work After Retirement.” RAND Labor and Population Working Paper Series WR-196-1. Santa Monica, CA: RAND.

McEvoy, Glenn M. and Wayne F. Cascio. 1989. "Cumulative Evidence of the Relationship Between Employee Age and Job Performance.” Journal of Applied Psychology 74(1): 1117.

McNaught, William, Michael C. Barth, and Peter H. Henderson. 1989. "The Human Resource Potential of Americans Over 50.” Human Resource Management 28(4): 455-473.

Mermin, Gordon B.T., Richard W. Johnson, and Dan Murphy. 2006. "Why Do Boomers Plan To Work So Long?” CRR Working Paper No. 2006-19. Chestnut Hill, MA: Center for Retirement Research at Boston College.

Munnell, Alicia H., Steven A. Sass, and Mauricio Soto. 2006. "Employer Attitudes Towards Older Workers: Survey Results.” Work Opportunities for Older Americans 3. Chestnut Hill, MA: Center for Retirement Research at Boston College.

Munnell, Alicia H., Steven Sass, Mauricio Soto, and Natalia Zhivan. 2006. "Has the Displacement of Older Workers Increased?” CRR Working Paper No. 2005-18. Chestnut Hill, MA: Center for Retirement Research at Boston College.

National Center for Health Statistics. 2006. “Trends in Health and Aging.” http://www.cdc.gov/nchs/agingact.htm. 
Ruhm, Christopher J. 1990. “Bridge Jobs and Partial Retirement.” Journal of Labor Economics 8(4): 482-501.

Social Security Trustees. 2006. The 2006 Annual Report of the Board of Trustees of the Federal Old-Age and Survivors Insurance and Federal Disability Insurance Trust Funds. http://www.ssa.gov/OACT/TR/TR06/tr06.pdf.

Steuerle, Eugene, Christopher Spiro, and Richard W. Johnson. 1999. “Can Americans Work Longer?” Straight Talk on Social Security and Retirement Policy No. 5. Washington, D.C.: The Urban Institute.

U.S. Census Bureau. 2004. “U.S. Interim Projections by Age, Sex, Race, and Hispanic Origin.” http://www.census.gov/ipc/www/usinterimproj/.

Verhaeghen, Paul and Timothy A. Salthouse. 1997. "Meta-Analyses of Age-Cognition Relations in Adulthood: Estimates of Linear and Nonlinear Age Effects and Structural Models.” Psychological Bulletin 122(3): 231-249. 
Table 1. Percent Distribution of Job Changes by Reason for Separation and Length of Previous Job

\begin{tabular}{lccccc}
\hline & All & Retirement & Layoff & Quit & Other \\
\hline $\begin{array}{l}\text { Percent of all job changes } \\
\begin{array}{l}\text { Percent of job changes, when previous } \\
\text { jobs lasted more than 10 years }\end{array}\end{array}$ & 100.0 & 18.0 & 32.8 & 29.6 & 19.6 \\
$\begin{array}{l}\text { Percent of job changes, when previous } \\
\text { jobs lasted 10 or fewer years }\end{array}$ & 100.0 & 34.9 & 29.5 & 18.9 & 16.8 \\
\hline
\end{tabular}

Source: Authors' estimates from the Health and Retirement Study (HRS).

Note: The sample consists of 8,362 changes between 1986 and 2004 by adults ages 45 to 75 . There were 3,268 job changes involving separations from jobs that lasted more than 10 years, and 5,194 involving separations from jobs that lasted 10 or fewer years. 
Table 2. Characteristics of Workers Who Change Jobs, by Reason for Job Separation and Length of Previous Job (\%)

\begin{tabular}{|c|c|c|c|c|}
\hline Al & Retirement & Layoff & $\mathbf{Q u}$ & Other \\
\hline
\end{tabular}

\begin{tabular}{|c|c|c|c|c|c|}
\hline \multicolumn{6}{|c|}{$\begin{array}{l}\text { Former Job Lasted More Than } 10 \text { Years } \\
\text { Gender }\end{array}$} \\
\hline Male & 60.1 & 67.1 & $61.0^{*}$ & $55.9 *$ & $48.7^{*}$ \\
\hline Female & 39.9 & 32.9 & $39.0^{*}$ & $44.1^{*}$ & $51.3^{*}$ \\
\hline \multicolumn{6}{|l|}{ Age } \\
\hline $45-50$ & 6.3 & 2.5 & $7.6^{*}$ & $11.0^{*}$ & $6.9 *$ \\
\hline $51-55$ & 45.1 & 33.3 & $52.9 *$ & $52.7 *$ & $47.2 *$ \\
\hline $56-60$ & 33.9 & 40.0 & $32.0^{*}$ & $30.1 *$ & $29.6^{*}$ \\
\hline $61-65$ & 11.7 & 21.3 & $5.3^{*}$ & $4.9^{*}$ & $10.8^{*}$ \\
\hline $66-75$ & 3.0 & 3.4 & 2.3 & $1.4^{*}$ & 5.5 \\
\hline \multicolumn{6}{|l|}{ Race } \\
\hline African American & 9.7 & 10.7 & 11.2 & $6.7^{*}$ & 8.5 \\
\hline Hispanic & 4.5 & 2.7 & $7.7^{*}$ & 2.4 & $5.2 *$ \\
\hline White non-Hispanic & 85.8 & 86.7 & $81.1^{*}$ & $90.9 *$ & 86.3 \\
\hline \multicolumn{6}{|l|}{ Education } \\
\hline Did not complete high school & 16.9 & 11.6 & $24.0^{*}$ & 14.5 & $18.0^{*}$ \\
\hline High school graduate & 48.5 & 47.0 & 50.4 & 47.2 & 49.4 \\
\hline Some college & 5.7 & 6.0 & 5.5 & 5.2 & 6.2 \\
\hline Four or more years of college & 29.0 & 35.5 & $20.1^{*}$ & 33.0 & $26.4^{*}$ \\
\hline$N$ & 3,268 & 1,167 & 996 & 576 & 529 \\
\hline \multirow{2}{*}{\multicolumn{6}{|c|}{$\begin{array}{l}\text { Former Job Lasted } 10 \text { or Fewer Years } \\
\text { Gender }\end{array}$}} \\
\hline & & & & & \\
\hline Male & 51.0 & 57.1 & 53.7 & 52.4 & $41.9 *$ \\
\hline Female & 49.0 & 42.9 & 46.3 & 47.6 & $58.1^{*}$ \\
\hline \multicolumn{6}{|l|}{ Age } \\
\hline $45-50$ & 5.4 & 0.0 & $6.4^{*}$ & $5.6^{*}$ & $5.5^{*}$ \\
\hline $51-55$ & 44.8 & 17.6 & $46.7^{*}$ & $49.8 *$ & $42.2 *$ \\
\hline $56-60$ & 33.4 & 31.4 & 34.5 & 31.9 & 34.9 \\
\hline $61-65$ & 11.6 & 38.7 & $8.5^{*}$ & $9.2^{*}$ & $11.4^{*}$ \\
\hline $66-75$ & 4.8 & 12.3 & $3.9 *$ & $3.5^{*}$ & $6.0^{*}$ \\
\hline \multicolumn{6}{|l|}{ Race } \\
\hline African American & 6.8 & 7.2 & 6.9 & 6.4 & 7.5 \\
\hline Hispanic & 6.8 & 4.8 & $9.0 *$ & 4.8 & 7.2 \\
\hline White non-Hispanic & 86.4 & 88.0 & 84.2 & 88.8 & 85.4 \\
\hline \multicolumn{6}{|l|}{ Education } \\
\hline Did not complete high school & 19.8 & 16.9 & $23.5^{*}$ & 16.3 & 20.7 \\
\hline High school graduate & 50.6 & 50.2 & 53.1 & 48.6 & 50.1 \\
\hline Some college & 5.8 & 4.3 & 4.0 & 6.6 & $8.1^{*}$ \\
\hline Four or more years of college & 23.8 & 28.6 & $19.4^{*}$ & 28.6 & $21.1^{*}$ \\
\hline$N$ & 5,194 & 397 & 1,806 & 1,890 & 1,101 \\
\hline
\end{tabular}

Source: Authors' estimates from the Health and Retirement Study (HRS).

Note: The sample consisted of job changes between 1986 and 2004 by adults ages 45 to 75 . An asterisk indicates significant differences $(p<.05)$ between retirees and those who separate for other reasons. Column subgroups do not always sum to 100 percent because of rounding. 
Table 3. Mean and Median Hourly Wages Among Older Job Changers on Old and New Jobs, by Reason for Job Separation and Length of Former Job (\$)

\begin{tabular}{|c|c|c|c|c|c|c|c|c|c|c|}
\hline & \multicolumn{2}{|c|}{ All } & \multicolumn{2}{|c|}{ Retirement } & \multicolumn{2}{|c|}{ Layoff } & \multicolumn{2}{|c|}{ Quit } & \multicolumn{2}{|c|}{ Other } \\
\hline & Old & New & Old & New & Old & New & Old & New & Old & New \\
\hline \multicolumn{11}{|l|}{ All Jobs } \\
\hline \multicolumn{11}{|l|}{ Men and Women } \\
\hline Mean Wage & 18.57 & $16.23 *$ & 24.90 & $15.94 *$ & 17.48 & $15.38 *$ & 17.22 & 17.79 & 16.58 & 15.48 \\
\hline Median Wage & 14.52 & $11.86^{*}$ & 21.92 & $10.86^{*}$ & 13.96 & $11.87 *$ & 13.14 & 13.14 & 12.19 & $10.78 *$ \\
\hline$N$ & 7,622 & 7,064 & 1,412 & 1,209 & 2,548 & 2,386 & 2,260 & 2,159 & 1,402 & 1,310 \\
\hline \multicolumn{11}{|l|}{ Men Only } \\
\hline Mean Wage & 22.23 & $19.27 *$ & 27.75 & $17.38^{*}$ & 20.88 & $17.96^{*}$ & 20.03 & 21.36 & 21.58 & 20.61 \\
\hline Median Wage & 18.67 & $14.03^{*}$ & 23.94 & $11.37 *$ & 17.13 & $14.28 *$ & 16.63 & 16.45 & 16.47 & 13.83* \\
\hline$N$ & 3,793 & 3,484 & 931 & 789 & 1,329 & 1,226 & 990 & 951 & 543 & 518 \\
\hline \multicolumn{11}{|l|}{ Women Only } \\
\hline Mean Wage & 14.28 & $12.92 *$ & 19.65 & $13.38 *$ & 13.18 & 12.32 & 14.13 & 14.16 & 12.78 & 11.84 \\
\hline Median Wage & 11.34 & $10.21^{*}$ & 17.22 & $9.99 *$ & 11.21 & $9.92 *$ & 10.73 & $10.86^{*}$ & 9.77 & $9.07 *$ \\
\hline$N$ & 3,829 & 3,850 & 481 & 420 & 1,219 & 1,160 & 1,270 & 1,208 & 859 & 792 \\
\hline \multicolumn{11}{|c|}{ Former Job Lasted More Than 10 Years } \\
\hline \multicolumn{11}{|c|}{ Men and Women } \\
\hline Mean Wage & 22.35 & $17.00 *$ & 27.11 & $16.50 *$ & 19.57 & $15.84 *$ & 20.47 & 18.86 & 19.15 & 17.92 \\
\hline Median Wage & 19.43 & $11.98^{*}$ & 23.85 & $11.23^{*}$ & 16.20 & $11.98 *$ & 17.13 & $14.73^{*}$ & 15.69 & $11.86^{*}$ \\
\hline$N$ & 2,952 & 2,648 & 1,070 & 904 & 920 & 838 & 522 & 497 & 440 & 409 \\
\hline \multicolumn{11}{|l|}{ Men Only } \\
\hline Mean Wage & 25.69 & $19.64 *$ & 29.47 & $18.15^{*}$ & 23.00 & $18.33^{*}$ & 22.38 & 21.44 & 24.60 & 24.06 \\
\hline Median Wage & 22.68 & $13.98^{*}$ & 25.25 & $11.86^{*}$ & 19.43 & $14.54 *$ & 19.95 & $17.45^{*}$ & 19.16 & $14.74 *$ \\
\hline$N$ & 1,712 & 1,536 & 732 & 614 & 520 & 479 & 260 & 247 & 200 & 196 \\
\hline \multicolumn{11}{|l|}{ Women Only } \\
\hline Mean Wage & 17.38 & $13.03^{*}$ & 22.10 & $13.04 *$ & 14.56 & $12.18^{*}$ & 18.02 & 15.55 & 14.40 & $11.63^{*}$ \\
\hline Median Wage & 14.94 & $10.34 *$ & 19.37 & $10.34 *$ & 12.88 & $10.30 *$ & 13.84 & 13.18 & 12.45 & $8.80 *$ \\
\hline$N$ & 1,240 & 1,112 & 338 & 290 & 400 & 359 & 262 & 250 & 240 & 213 \\
\hline \multirow{2}{*}{\multicolumn{11}{|c|}{ Former Job Lasted 10 or Fewer Years }} \\
\hline & & & & & & & & & & \\
\hline Mean Wage & 16.18 & 15.78 & 17.88 & $14.33^{*}$ & 16.35 & $15.14 *$ & 16.16 & $17.46^{*}$ & 15.37 & 14.39 \\
\hline Median Wage & 12.14 & $11.54^{*}$ & 13.03 & $9.99 *$ & 12.93 & $11.86^{*}$ & 11.98 & $12.45^{*}$ & 11.06 & 10.54 \\
\hline$N$ & 4,670 & 4,416 & 342 & 305 & 1,628 & 1,548 & 1,738 & 1,662 & 962 & 901 \\
\hline \multicolumn{11}{|l|}{ Men Only } \\
\hline Mean Wage & 19.63 & 19.00 & 20.98 & $14.56 *$ & 19.63 & $17.74 *$ & 19.19 & $21.33^{*}$ & 20.00 & 18.52 \\
\hline Median Wage & 15.28 & $14.13^{*}$ & 14.99 & $10.34^{*}$ & 15.69 & $14.09 *$ & 15.27 & 16.18 & 14.67 & 13.25 \\
\hline$N$ & 2,081 & 1,948 & 199 & 175 & 809 & 747 & 730 & 704 & 343 & 322 \\
\hline \multicolumn{11}{|l|}{ Women Only } \\
\hline Mean Wage & 12.69 & 12.87 & 14.14 & 14.05 & 12.52 & 12.39 & 12.99 & 13.80 & 12.10 & 11.91 \\
\hline Median Wage & 10.21 & 9.96 & 11.00 & $9.59 *$ & 10.52 & $9.82 *$ & 10.18 & $10.60^{*}$ & 9.32 & 9.22 \\
\hline$N$ & 2,589 & 2,468 & 143 & 130 & 819 & 801 & 1,008 & 958 & 619 & 579 \\
\hline
\end{tabular}

Source: Authors' estimates from the Health and Retirement Study (HRS).

Note: The sample consisted of job changes between 1986 and 2004 by adults ages 45 to 75 . An asterisk indicates significant differences $(p<.05)$ between wages on old and new jobs. Missing wage information led to differences in the number of observations for old and new jobs. 
Table 4. Changes in Hourly Wage Among Older Job Changers, by Reason for Job Separation and Length of Former Job (\%)

All Retirement Layoff Quit Other

\section{Former Job Lasted More Than 10 Years}

Men and Women

Absolute change of less than $10 \%$

25.9

16.1

Decrease of $10 \%$ or more, but less than $25 \%$

9.9

Decrease of $25 \%$ or more, but less than $50 \%$

19.2

Decrease of $50 \%$ or more

29.0

2,549

15.0
9.7
6.7
21.8
46.7
893

$\begin{array}{lrr}26.9^{*} & 38.5^{*} & 31.5^{*} \\ 19.4^{*} & 20.3^{*} & 18.0^{*} \\ 10.9^{*} & 10.9^{*} & 13.4^{*} \\ 20.8 & 15.8^{*} & 14.3^{*} \\ 21.9^{*} & 14.6^{*} & 22.8^{*} \\ 813 & 463 & 380\end{array}$

\section{Men Only}

Increase of $10 \%$ or more

25.3

16.7

Absolute change of less than $10 \%$

14.8

8.1

24.9*

$38.8^{*}$

$32.7^{*}$

$\begin{array}{ll}8.7 & 6.7\end{array}$

$19.4^{*}$

$20.2^{*}$

$15.4^{*}$

Decrease of $10 \%$ or more, but less than $25 \%$

18.6

Decrease of $50 \%$ or more

18.5

32.7

49.9

$N$

1,482

610

22.1

24.8*

9.4

$13.7^{*}$

14.3

$16.2 *$

$24.0 *$

\section{Women Only}

Increase of $10 \%$ or more

Absolute change of less than $10 \%$

26.7

18.2

11.3

13.3

Decrease of $10 \%$ or more, but less than $25 \%$

11.6

Decrease of $25 \%$ or more, but less than $50 \%$

20.2

6.8

Decrease of $50 \%$ or more

23.3

28.7

39.8

$N$

1,067

283

464

231

177

\section{Former Job Lasted 10 or Fewer Years}

\section{Men and Women}

Increase of $10 \%$ or more

39.2

25.9

29.7

Absolute change of less than 10\%

12.8

18.7

Decrease of $10 \%$ or more, but less than $25 \%$

12.5

Decrease of $25 \%$ or more, but less than $50 \%$

13.1

22.8

Decrease of $50 \%$ or more

16.4

$N$

4,159

283

$30.1^{*}$

$38.1^{*}$

30.3*

19.5

20.3

20.5

$14.1^{*}$

12.9

$19.0^{*}$

$16.3^{*}$

13.0

$17.4^{*}$

14.4*

349

$12.4 *$

$21.7^{*}$

203

\section{Men Only}

Increase of $10 \%$ or more

Absolute change of less than $10 \%$

39.9

24.4

31.2

14.6

Decrease of $10 \%$ or more, but less than $25 \%$

12.8

Decrease of $25 \%$ or more, but less than $50 \%$

12.8

15.0

Decrease of $50 \%$ or more

21.7

10.1

17.5

$N$

1,824

157

$\begin{array}{lcc}33.0 & 48.5^{*} & 35.9 \\ 26.2^{*} & 25.4^{*} & 28.6^{*} \\ 16.0 & 9.8 & 13.0 \\ 14.4^{*} & 10.2^{*} & 12.9^{*} \\ 10.4^{*} & 6.1^{*} & 9.6^{*} \\ 1,455 & 1,574 & 847\end{array}$

\section{Women Only}

Increase of $10 \%$ or more 38.5

Absolute change of less than $10 \%$

$38.5 \quad 28.1$

$27.4 \quad 22.9$

Decrease of $10 \%$ or more, but less than $25 \%$

12.9

22.9
9.8

$13.3 \quad 23.9$

Decrease of $25 \%$ or more, but less than $50 \%$

Decrease of $50 \%$ or more

8.0

15.3

$N$

2,335

126

$\begin{array}{lcl}33.3 & 48.0^{*} & 40.3 \\ 24.5^{*} & 25.6^{*} & 25.5^{*} \\ 16.4 & 9.1 & 12.1 \\ 14.1 & 10.5^{*} & 11.6^{*} \\ 11.7 & 6.9^{*} & 10.6 \\ 712 & 652 & 303\end{array}$

$\begin{array}{ccc}32.7 & 49.0^{*} & 32.8 \\ 28.1 & 25.2 & 30.8 \\ 15.6 & 10.6 & 13.6 \\ 14.8 & 10.0^{*} & 13.7^{*} \\ 8.9 & 5.2^{*} & 9.0 \\ 743 & 922 & 544\end{array}$

Source: Authors' estimates from the Health and Retirement Study (HRS).

Note: The sample consisted of job changes between 1986 and 2004 by adults ages 45 to 75 . An asterisk indicates significant differences $(p<.05)$ between retirees and those who separate for other reasons. 
Table 5. Occupations of Older Job Changers on Old and New Jobs, by Reason for Job Separation and Length of Former Job (\%)

\begin{tabular}{|c|c|c|c|c|c|c|c|c|c|c|}
\hline & \multicolumn{2}{|c|}{ All } & \multicolumn{2}{|c|}{ Retirement } & \multicolumn{2}{|c|}{ Layoff } & \multicolumn{2}{|c|}{ Quit } & \multicolumn{2}{|c|}{ Other } \\
\hline & Old & New & Old & New & Old & New & Old & New & Old & New \\
\hline \multicolumn{11}{|c|}{ FORMER JOB LASTED MORE THAN 10 YEARS } \\
\hline \multicolumn{11}{|l|}{ Occupational Distribution } \\
\hline Managerial & 21.3 & $13.4 *$ & 21.9 & $12.8 *$ & 23.4 & $12.0^{*}$ & 19.7 & 17.9 & 18.2 & $12.3^{*}$ \\
\hline Professional specialty & 19.2 & 17.5 & 25.8 & 22.8 & 11.0 & 11.2 & 21.1 & 18.5 & 18.4 & 16.6 \\
\hline Sales & 9.0 & $12.9 *$ & 4.6 & $11.9 *$ & 9.6 & $13.3^{*}$ & 14.5 & 10.7 & 10.7 & $16.5^{*}$ \\
\hline Clerical & 13.7 & 13.8 & 14.7 & 11.7 & 14.5 & 13.9 & 11.6 & $17.7 *$ & 12.6 & 13.5 \\
\hline Services & 9.4 & $15.9 *$ & 8.9 & $15.1^{*}$ & 7.3 & $16.0^{*}$ & 9.8 & 13.3 & 13.5 & $20.1^{*}$ \\
\hline $\begin{array}{l}\text { Farming, fishing, } \\
\text { forestry }\end{array}$ & 2.2 & $3.5 *$ & 1.2 & $5.0 *$ & 2.1 & 2.5 & 2.4 & 2.1 & 4.0 & 3.9 \\
\hline Mechanical & 12.4 & $9.9 *$ & 12.0 & 9.4 & 14.1 & 11.7 & 12.0 & 9.9 & 10.5 & 7.7 \\
\hline Operators & 12.9 & 13.1 & 10.8 & 11.3 & 18.1 & 19.4 & 9.0 & 10.0 & 12.3 & 9.5 \\
\hline$N$ & 3,239 & 3,241 & 1,142 & 1,152 & 993 & 992 & 576 & 577 & 528 & 520 \\
\hline \multicolumn{11}{|l|}{ Change in Occupation } \\
\hline Same detailed & \multirow{2}{*}{\multicolumn{2}{|c|}{23.2}} & \multirow{2}{*}{\multicolumn{2}{|c|}{14.9}} & \multirow{2}{*}{\multicolumn{2}{|c|}{$25.0^{*}$}} & \multirow{2}{*}{\multicolumn{2}{|c|}{$33.2^{*}$}} & \multirow{2}{*}{\multicolumn{2}{|c|}{$25.5^{*}$}} \\
\hline occupational group & & & & & & & & & & \\
\hline $\begin{array}{l}\text { Different detailed group } \\
\text { same broad group }\end{array}$ & \multicolumn{2}{|c|}{19.4} & \multicolumn{2}{|c|}{20.8} & \multicolumn{2}{|c|}{18.1} & \multicolumn{2}{|c|}{21.1} & \multicolumn{2}{|c|}{16.8} \\
\hline Different broad group & \multicolumn{2}{|c|}{57.4} & \multicolumn{2}{|c|}{64.3} & \multicolumn{2}{|c|}{$57.0^{*}$} & \multicolumn{2}{|c|}{$45.8^{*}$} & \multicolumn{2}{|c|}{57.7} \\
\hline$N$ & \multicolumn{2}{|c|}{2,845} & \multicolumn{2}{|c|}{997} & & & & & & \\
\hline FORMER JOB LASTE & 10 OR F & EWER & ARS & & & & & & & \\
\hline Occupational Distributi & & & & & & & & & & \\
\hline Managerial & 17.2 & $13.8^{*}$ & 15.0 & 14.0 & 18.6 & $11.2^{*}$ & 17.0 & 17.4 & 16.2 & $11.8^{*}$ \\
\hline Professional specialty & 13.4 & 14.2 & 18.9 & 15.0 & 10.2 & 10.8 & 15.1 & 16.7 & 13.9 & 15.1 \\
\hline Sales & 14.0 & 14.2 & 8.4 & 10.9 & 11.8 & 13.4 & 17.3 & 15.0 & 13.7 & 15.1 \\
\hline Clerical & 15.6 & 16.7 & 15.3 & 12.8 & 17.2 & 18.4 & 13.6 & 14.4 & 16.7 & 18.9 \\
\hline Services & 14.6 & 16.3 & 14.1 & 18.2 & 12.9 & $15.8^{*}$ & 13.9 & 13.7 & 18.7 & 20.4 \\
\hline Farming, fishing, & & & & & & & & & & \\
\hline forestry & 1.9 & 1.9 & 3.3 & 4.0 & 2.4 & 2.4 & 1.1 & 1.2 & 2.0 & 1.5 \\
\hline Mechanical & 9.4 & 9.1 & 7.7 & 8.1 & 11.5 & 11.1 & 8.2 & 8.7 & 8.7 & 7.0 \\
\hline Operators & 13.9 & 14.0 & 17.4 & 17.1 & 15.4 & 16.9 & 14.0 & 12.9 & 10.1 & 10.2 \\
\hline$N$ & 5,167 & 5,135 & 393 & 394 & 1,795 & 1,786 & 1,886 & 1,877 & 1,093 & 1,078 \\
\hline Change in Occupation & & & & & & & & & & \\
\hline Same detailed & & & & & & & & & & \\
\hline occupational group & 27 & & 20 & & & & & .7* & & $.8^{*}$ \\
\hline $\begin{array}{l}\text { Different detailed group } \\
\text { same broad group }\end{array}$ & 13 & & 14 & & & & & & & \\
\hline Different broad group & 59 & & 64 & & 60 & & & $2 *$ & & $.6 *$ \\
\hline$N$ & $3, \varepsilon$ & & & 30 & & & & & & 58 \\
\hline
\end{tabular}

Source: Authors' estimates from the Health and Retirement Study (HRS).

Note: The sample consisted of job changes between 1986 and 2004 by adults ages 45 to 75 . An asterisk indicates significant differences $(p<.05)$ between occupations on old and new jobs. Missing occupation information led to differences in the number of observations for old and new jobs. 
Table 6. Industry of Older Job Changers on Old and New Jobs, by Reason for Job Separation and Length of Former Job (\%)

\begin{tabular}{|c|c|c|c|c|c|c|c|c|c|c|}
\hline & \multicolumn{2}{|c|}{ All } & \multicolumn{2}{|c|}{ Retirement } & \multicolumn{2}{|c|}{ Layoff } & \multicolumn{2}{|c|}{ Quit } & \multicolumn{2}{|c|}{ Other } \\
\hline & Old & New & Old & New & Old & New & Old & New & Old & New \\
\hline \multicolumn{11}{|c|}{ FORMER JOB LASTED MORE THAN 10 YEARS } \\
\hline \multicolumn{11}{|l|}{ Occupational Distribution } \\
\hline \multicolumn{11}{|l|}{ Agriculture, forestry, } \\
\hline Fishing & 2.7 & $3.8^{*}$ & 1.6 & $5.2^{*}$ & 2.7 & 2.7 & 2.6 & 2.5 & 5.2 & 4.2 \\
\hline Mining, construction & 7.7 & 8.2 & 5.1 & $7.7^{*}$ & 9.7 & 9.3 & 6.6 & 8.1 & 10.6 & 7.5 \\
\hline Manufacturing & 21.4 & $11.4^{*}$ & 21.7 & $6.9 *$ & 30.1 & $18.2^{*}$ & 15.0 & 11.2 & 12.5 & 8.9 \\
\hline Transportation & 9.3 & $6.1^{*}$ & 12.4 & $5.7^{*}$ & 8.9 & 6.4 & 5.4 & 6.1 & 8.0 & 6.5 \\
\hline Trade & 13.5 & $16.8^{*}$ & 5.0 & $13.9 *$ & 18.2 & 20.5 & 18.9 & 16.0 & 16.8 & 17.4 \\
\hline \multicolumn{11}{|l|}{ Finance, insurance, } \\
\hline Business, repair services & 4.5 & $10.2^{*}$ & 2.1 & $12.2^{*}$ & 6.2 & $9.7^{*}$ & 4.9 & 8.7 & 6.2 & 8.9 \\
\hline \multicolumn{11}{|l|}{ Entertainment, } \\
\hline recreation services & 4.0 & $7.5^{*}$ & 1.3 & $7.9 *$ & 4.0 & $7.2 *$ & 6.4 & 7.6 & 6.6 & 6.9 \\
\hline Professional services & 21.9 & $24.7 *$ & 29.1 & 29.0 & 10.2 & $16.7^{*}$ & 25.8 & 26.7 & 23.0 & 27.4 \\
\hline Public administration & 8.1 & $3.6^{*}$ & 17.1 & $4.4^{*}$ & 1.5 & 2.8 & 4.8 & 4.3 & 4.6 & 2.6 \\
\hline$N$ & 3,255 & 3,224 & 1,161 & 1,149 & 993 & 989 & 575 & 568 & 526 & 518 \\
\hline \multicolumn{11}{|l|}{ Change in Industry } \\
\hline Same detailed & \multirow{2}{*}{\multicolumn{2}{|c|}{27.3}} & \multirow{2}{*}{\multicolumn{2}{|c|}{20.3}} & \multirow{2}{*}{\multicolumn{2}{|c|}{$27.8^{*}$}} & \multirow{3}{*}{\multicolumn{2}{|c|}{$33.7 *$}} & \multirow{2}{*}{\multicolumn{2}{|c|}{$32.8 *$}} \\
\hline occupational group & & & & & & & & & & \\
\hline Different detailed group & \multirow{2}{*}{\multicolumn{2}{|c|}{13.7}} & & & & & & & & \\
\hline same broad group & & & \multicolumn{2}{|c|}{14.8} & \multicolumn{2}{|c|}{12.2} & \multicolumn{2}{|c|}{14.1} & \multicolumn{2}{|c|}{13.7} \\
\hline Different broad group & \multicolumn{2}{|c|}{59.0} & 64 & & 60. & & & 2* & 53. & \\
\hline$N$ & & & & 7 & 86 & & & & 47 & 1 \\
\hline FORMER JOB LASTED & OR Fl & WER Y & RS & & & & & & & \\
\hline $\begin{array}{l}\text { Occupational Distribution } \\
\text { Agriculture, forestry, }\end{array}$ & & & & & & & & & & \\
\hline fishing & 2.0 & 1.8 & 3.4 & 3.6 & 2.6 & 2.1 & 1.1 & 1.5 & 1.9 & 1.4 \\
\hline Mining, construction & 8.1 & 7.3 & 5.0 & 6.8 & 11.6 & 10.1 & 5.8 & 6.3 & 7.3 & 4.9 \\
\hline Manufacturing & 13.1 & 11.6 & 11.3 & 9.5 & 17.5 & $13.1^{*}$ & 11.5 & 11.1 & 9.4 & 10.7 \\
\hline Transportation & 7.1 & 6.4 & 8.4 & 8.5 & 6.6 & 5.9 & 8.0 & 7.5 & 5.7 & 4.7 \\
\hline Trade & 20.2 & 19.5 & 14.6 & 13.6 & 19.4 & 19.9 & 22.3 & 20.1 & 19.8 & 19.9 \\
\hline $\begin{array}{l}\text { Finance, insurance, } \\
\text { real estate }\end{array}$ & 7.7 & 7.7 & 8.7 & 7.8 & 7.1 & 7.8 & 7.3 & 7.8 & 8.8 & 7.4 \\
\hline Business, repair services & 9.7 & 9.2 & 7.6 & 9.3 & 9.4 & 9.0 & 10.7 & 8.8 & 9.1 & 10.2 \\
\hline $\begin{array}{l}\text { Entertainment, } \\
\text { recreation services }\end{array}$ & 6.4 & $7.7^{*}$ & 5.6 & 8.9 & 6.6 & & 5.0 & & 8.7 & 9.8 \\
\hline Professional services & 23.3 & $25.7^{*}$ & 30.7 & 28.9 & 16.5 & $21.6^{*}$ & 26.4 & 27.4 & 26.5 & 28.2 \\
\hline Public administration & 2.6 & 3.0 & 4.8 & 3.0 & 2.7 & 2.7 & 2.0 & $3.4^{*}$ & 2.9 & 2.8 \\
\hline$N$ & 5,134 & 5,104 & 392 & 391 & 1,782 & 1,774 & 1,874 & 1,861 & 1,086 & 1,078 \\
\hline Change in Industry & & & & & & & & & & \\
\hline $\begin{array}{l}\text { Same detailed } \\
\text { occupational group }\end{array}$ & 30 & & 25 & & 29. & & & $2 *$ & 32. & \\
\hline Different detailed group & & & & & & & & & & \\
\hline same broad group & 16 & & 16 & & 15. & & & & 17. & \\
\hline Different broad group & 52 & & 58 & & 55. & & & 5* & 50. & \\
\hline$N$ & & & 3 & 30 & 1,3 & & & & 86 & 8 \\
\hline
\end{tabular}

Source: Authors' estimates from the Health and Retirement Study (HRS).

Note: The sample consisted of job changes between 1986 and 2004 by adults ages 45 to 75 . Asterisks indicate significant differences $(p<.05)$ between old and new jobs. Missing industry information led to differences in the number of observations for old and new jobs. 
Table 7. Fringe Benefit Changes Among Older Job Changers, by Reason for Job Separation and Length of Former Job (\%)

All Retirement Layoff $\quad$ Quit $\quad$ Other

Former Job Lasted More Than Years

\section{Pension}

Covered on old job

Covered on new job

Covered on old job, not on new job

Covered on new job, not on old job

$N$

\section{Health Benefits}

Covered on old job

Covered on new job

Covered on old job, not on new job

Covered on new job, not on old job

$N$

\section{Former Job Lasted 10 or Fewer Years}

\section{Pension}

Covered on old job

Covered on new job

Covered on old job, not on new job

Covered on new job, not on old job

$N$

\section{Health Benefits}

Covered on old job

Covered on new job

Covered on old job, not on new job

Covered on new job, not on old job

$N$

$\begin{array}{rc}70.9 & 90.9 \\ 25.9 & 15.2 \\ 50.6 & 76.3 \\ 5.6 & 0.6 \\ 3,209 & 1,153\end{array}$

$\begin{array}{rrr}64.0^{*} & 58.2^{*} & 55.4^{*} \\ 30.0^{*} & 39.3^{*} & 25.8^{*} \\ 40.3^{*} & 30.8^{*} & 36.9^{*} \\ 6.3^{*} & 11.9^{*} & 7.3^{*} \\ 969 & 565 & 522\end{array}$

70.7

82.4

23.1

6.9

1,732
$61.4^{*}$

56.3

$14.3^{*}$

9.2

247
$57.1^{*}$

$44.5^{*}$

21.0

8.4

312
34.0

27.2

19.3

12.5

5,112

50.1

45.6

16.4

11.9

3,787
61.0

26.3

4.9

45.2
14.6
36.9
6.3
391

60.3
35.9
30.0
5.6
339

34.1 *

$26.6^{*}$

18.5*

$11.0^{*}$

1,772

$66.5^{*}$

$50.0^{*}$

24.4

7.9

461

Source: Authors’ estimates from the Health and Retirement Study (HRS).

Note: The sample consisted of job changes between 1986 and 2004 by adults ages 45 to 75. An asterisk indicates significant differences $(p<.05)$ between retirees and those who separate for other reasons. 
Table 8. Changes in Part-Time Status, Self-Employment, Hours Flexibility, and Union Status Among Older Job Changers, by Reason for Job Separation and Length of Former Job

\begin{tabular}{|c|c|c|c|c|c|}
\hline & All & Retirement & Layoff & Quit & Other \\
\hline \multicolumn{6}{|c|}{ Former Job Lasted More Than Years } \\
\hline \multicolumn{6}{|l|}{ Part-Time Status } \\
\hline Old job & 14.9 & 10.8 & 12.6 & $15.2 *$ & $27.0^{*}$ \\
\hline New job & 43.0 & 64.7 & $27.3^{*}$ & $24.5^{*}$ & $47.5^{*}$ \\
\hline Old job, not new job & 5.4 & 2.3 & $5.1 *$ & $7.9 *$ & $9.5^{*}$ \\
\hline New job, not old job & 33.5 & 56.2 & $19.8^{*}$ & $17.2^{*}$ & $30.0^{*}$ \\
\hline$N$ & 3.158 & 1.112 & 978 & 565 & 503 \\
\hline \multicolumn{6}{|l|}{ Self-Employed } \\
\hline Old job & 15.3 & 5.3 & $15.4^{*}$ & $19.1^{*}$ & $31.8^{*}$ \\
\hline New job & 24.5 & 30.7 & $19.7 *$ & $19.3^{*}$ & 26.2 \\
\hline Old job, not new job & 11.2 & 3.0 & $11.2 *$ & $16.1^{*}$ & $22.7^{*}$ \\
\hline New job, not old job & 20.4 & 28.4 & $15.5^{*}$ & $16.3^{*}$ & $17.1^{*}$ \\
\hline$N$ & 3.274 & 1.169 & 998 & 578 & 529 \\
\hline \multicolumn{6}{|l|}{ Flexible Work Hours } \\
\hline Old job & 27.5 & 22.5 & 28.1 & $41.6^{*}$ & 27.2 \\
\hline New job & 50.3 & 60.0 & $38.4 *$ & $43.6 *$ & 52.2 \\
\hline Old job, not new job & 10.7 & 7.5 & 12.3 & $18.2^{*}$ & 9.0 \\
\hline New job, not old job & 33.5 & 45.0 & $22.6 *$ & $20.2^{*}$ & 34.0 \\
\hline$N$ & 1.132 & 488 & 340 & 162 & 142 \\
\hline \multicolumn{6}{|c|}{ Covered by Union Contract } \\
\hline Old job & 32.6 & 43.1 & $22.3 *$ & $19.9 *$ & 35.4 \\
\hline New job & 10.5 & 8.3 & 13.2 & 10.9 & 11.5 \\
\hline Old job, not new job & 24.4 & 36.2 & $12.1 *$ & $12.5^{*}$ & 26.4 \\
\hline New job, not old job & 2.3 & 1.4 & 3.0 & 3.5 & 2.5 \\
\hline$N$ & 1.171 & 500 & 352 & 171 & 148 \\
\hline \multicolumn{6}{|c|}{ Former Job Lasted 10 or Fewer Years } \\
\hline \multicolumn{6}{|l|}{ Part-Time Status } \\
\hline Old job & 27.1 & 31.4 & $22.8^{*}$ & 27.5 & 32.4 \\
\hline New job & 34.9 & 67.4 & $31.6^{*}$ & $28.2^{*}$ & $41.5^{*}$ \\
\hline Old job, not new job & 10.3 & 8.0 & 8.3 & $12.0 *$ & 11.4 \\
\hline New job, not old job & 18.1 & 44.0 & $17.1^{*}$ & $12.7 *$ & $20.5^{*}$ \\
\hline$N$ & 5.013 & 372 & 1.750 & 1.847 & 1.044 \\
\hline \multicolumn{6}{|l|}{ Self-Employed } \\
\hline Old job & 11.1 & 10.8 & 7.8 & 9.0 & $20.3^{*}$ \\
\hline New job & 17.4 & 27.1 & $15.7^{*}$ & $15.1^{*}$ & $20.7^{*}$ \\
\hline Old job, not new job & 8.6 & 5.2 & 6.1 & 7.8 & $15.5^{*}$ \\
\hline New job, not old job & 14.9 & 21.5 & $14.0^{*}$ & $13.9 *$ & 15.9 \\
\hline$N$ & 5.206 & 399 & 1.807 & 1.895 & 1.105 \\
\hline \multicolumn{6}{|l|}{ Flexible Work Hours } \\
\hline Old job & 38.3 & 40.2 & 35.8 & 38.2 & 42.5 \\
\hline New job & 40.4 & 54.1 & $37.9 *$ & $37.5 *$ & 45.4 \\
\hline Old job, not new job & 17.5 & 13.9 & 16.5 & 19.0 & 17.8 \\
\hline New job, not old job & 19.6 & 27.8 & $18.6^{*}$ & $18.3^{*}$ & 20.7 \\
\hline$N$ & 2.866 & 234 & 997 & 1.127 & 508 \\
\hline \multicolumn{6}{|c|}{ Covered by Union Contract } \\
\hline Old job & 8.7 & 14.2 & 10.0 & $6.6^{*}$ & $8.1^{*}$ \\
\hline New job & 8.9 & 5.1 & $10.0^{*}$ & 8.9 & 8.0 \\
\hline Old job, not new job & 4.4 & 11.6 & $3.9 *$ & $3.5^{*}$ & $4.1^{*}$ \\
\hline New job, not old job & 4.6 & 2.5 & 3.9 & $5.8^{*}$ & 4.0 \\
\hline$N$ & 2.983 & 245 & 1.032 & 1.165 & 541 \\
\hline
\end{tabular}

Source: Authors' estimates from the Health and Retirement Study (HRS).

Note: The sample consisted of job changes between 1986 and 2004 by adults ages 45 to 75. An asterisk indicates significant differences ( $p<.05$ ) between retirees and those who separate for other reasons. 
Table 9. Changes in Job Satisfaction and Job Requirements Among Older Job Changers, by Reason for Job Separation and Length of Former Job

\begin{tabular}{|c|c|c|c|c|c|}
\hline & All & Retirement & Layoff & Quit & Other \\
\hline \multicolumn{6}{|c|}{ Former Job Lasted More Than 10 Years } \\
\hline \multicolumn{6}{|l|}{ Enjoy Work } \\
\hline Old job & 82.2 & 76.8 & $85.4^{*}$ & $85.2^{*}$ & $88.2^{*}$ \\
\hline New job & 91.6 & 92.5 & 91.9 & 94.6 & 86.7 \\
\hline Old job, not new job & 4.5 & 3.6 & 4.7 & 3.0 & 7.7 \\
\hline New job, not old job & 13.9 & 19.3 & $11.2^{*}$ & $12.4^{*}$ & $6.2^{*}$ \\
\hline$N$ & 1.352 & 565 & 329 & 193 & 265 \\
\hline \multicolumn{6}{|l|}{ Work Is Stressful } \\
\hline Old job & 67.9 & 68.8 & 67.6 & 62.5 & 70.4 \\
\hline New job & 39.0 & 30.9 & $47.5^{*}$ & $42.1^{*}$ & $42.5^{*}$ \\
\hline Old job, not new job & 35.7 & 42.5 & $29.1 *$ & $29.9 *$ & $34.0^{*}$ \\
\hline New job, not old job & 6.8 & 4.6 & $9.0^{*}$ & 9.5 & 6.1 \\
\hline$N$ & 1.755 & 719 & 465 & 258 & 313 \\
\hline \multicolumn{6}{|c|}{ Work Involves Physical Effort } \\
\hline Old job & 33.8 & 28.4 & $36.1^{*}$ & $43.2^{*}$ & 35.0 \\
\hline New job & 31.2 & 25.8 & $39.8 *$ & 28.0 & $34.0 *$ \\
\hline Old job, not new job & 14.1 & 15.1 & $9.3^{*}$ & $22.3^{*}$ & 11.7 \\
\hline New job, not old job & 11.5 & 12.5 & 13.0 & $7.1^{*}$ & 10.7 \\
\hline$N$ & 1.755 & 719 & 465 & 258 & 313 \\
\hline \multicolumn{6}{|c|}{ Make Pay and Promotion Decisions } \\
\hline Old job & 22.9 & 24.8 & $18.6^{*}$ & 24.8 & 21.9 \\
\hline New job & 14.2 & 14.1 & 10.7 & 17.2 & 17.6 \\
\hline Old job, not new job & 11.6 & 12.5 & 11.7 & 11.8 & 7.8 \\
\hline New job, not old job & 2.9 & 1.8 & 3.8 & 4.2 & 3.5 \\
\hline$N$ & 1.567 & 717 & 421 & 214 & 215 \\
\hline \multicolumn{6}{|c|}{ Former Job Lasted 10 or Fewer Years } \\
\hline \multicolumn{6}{|l|}{ Enjoy Work } \\
\hline Old job & 87.4 & 87.7 & 87.1 & 85.5 & 90.9 \\
\hline New job & 90.8 & 93.5 & 88.3* & 91.5 & 92.2 \\
\hline Old job, not new job & 6.1 & 3.3 & $8.8^{*}$ & 5.6 & 4.5 \\
\hline New job, not old job & 9.5 & 9.1 & 10.0 & 11.6 & 5.8 \\
\hline$N$ & 2.932 & 289 & 899 & 1.065 & 679 \\
\hline \multicolumn{6}{|l|}{ Work Is Stressful } \\
\hline Old job & 52.4 & 52.7 & 51.6 & 53.7 & 51.4 \\
\hline New job & 44.9 & 29.5 & $45.4^{*}$ & $49.5^{*}$ & $42.1^{*}$ \\
\hline Old job, not new job & 22.1 & 30.1 & $21.8^{*}$ & $20.1^{*}$ & $22.9 *$ \\
\hline New job, not old job & 14.6 & 6.9 & $15.6^{*}$ & $15.9 *$ & $13.6^{*}$ \\
\hline$N$ & 3.763 & 316 & 1.238 & 1.419 & 790 \\
\hline \multicolumn{6}{|c|}{ Work Involves Physical Effort } \\
\hline Old job & 33.9 & 36.7 & 33.5 & 33.1 & 34.8 \\
\hline New job & 32.6 & 26.0 & $36.8^{*}$ & 29.7 & $34.0^{*}$ \\
\hline Old job, not new job & 13.6 & 18.9 & $11.5^{*}$ & 14.1 & 13.8 \\
\hline New job, not old job & 12.3 & 8.2 & $14.8^{*}$ & 10.7 & $13.0^{*}$ \\
\hline$N$ & 3.763 & 316 & 1,238 & 1.419 & 790 \\
\hline \multicolumn{6}{|c|}{ Make Pay and Promotion Decisions } \\
\hline Old job & 14.8 & 13.2 & 14.0 & 15.7 & 15.1 \\
\hline New job & 11.9 & 6.7 & 8.6 & $16.1^{*}$ & $12.0^{*}$ \\
\hline Old job, not new job & 6.6 & 7.7 & 7.5 & 6.1 & 5.5 \\
\hline New job, not old job & 3.7 & 1.2 & 2.1 & $6.5^{*}$ & 2.4 \\
\hline$N$ & 3.681 & 335 & 1.222 & 1.383 & 741 \\
\hline
\end{tabular}

Source: Authors' estimates from the Health and Retirement Study (HRS).

Note: The sample consisted of job changes between 1986 and 2004 by adults ages 45 to 75 . An asterisk indicates significant differences ( $p<.05$ ) between retirees and those who separate for other reasons. 


\section{RECENT WORKING PAPERS FROM THE}

\section{CENTER FOR RETIREMENT RESEARCH AT BOSTON COLLEGE}

Cross-National Comparison of Income and Wealth Status in Retirement: First Results from the Luxembourg Wealth Study (LWS)

Eva Sierminska, Andrea Brandolini and Timothy M. Smeeding, February 2007

Saving and Demographic Change: The Global Dimension

Barry Bosworth and Gabriel Chodorow-Reich, February 2007

The Repeal of the Retirement Earnings Test and the Labor Supply of Older Men Gary V. Engelhardt and Anil Kumar, February 2007

Persistence in Labor Supply and the Response to the Social Security Earnings Test Leora Friedberg and Anthony Webb, December 2006

Annuitized Wealth and Consumption at Older Ages

Barbara A. Butrica and Gordon B.T. Mermin, December 2006

Risk and Reward of International Investing for U.S. Retirement Savers:

Historical Evidence

Gary Burtless, December 2006

State Age Protection Laws and the Age Discrimination in Employment Act Joanna Lahey, November 2006

Age, Women, and Hiring: An Experimental Study

Joanna Lahey, November 2006

Optimal Retirement Asset Decumulation Strategies: The Impact of Housing Wealth Anthony Webb, Robert Triest, and Wei Sun, November 2006

The Impact of Aggregate Mortality Rise on Defined Benefit Pension Plans Irena Dushi, Leora Friedberg, and Anthony Webb, November 2006

Health Care Costs, Taxes, and the Retirement Decision: Conceptual Issues and Illustrative Simulations

Rudolph G. Penner and Richard W. Johnson, November 2006

All working papers are available on the Center for Retirement Research website (http://www.bc.edu/crr) and can be requested by e-mail (crr@bc.edu) or phone (617-552-1762). 